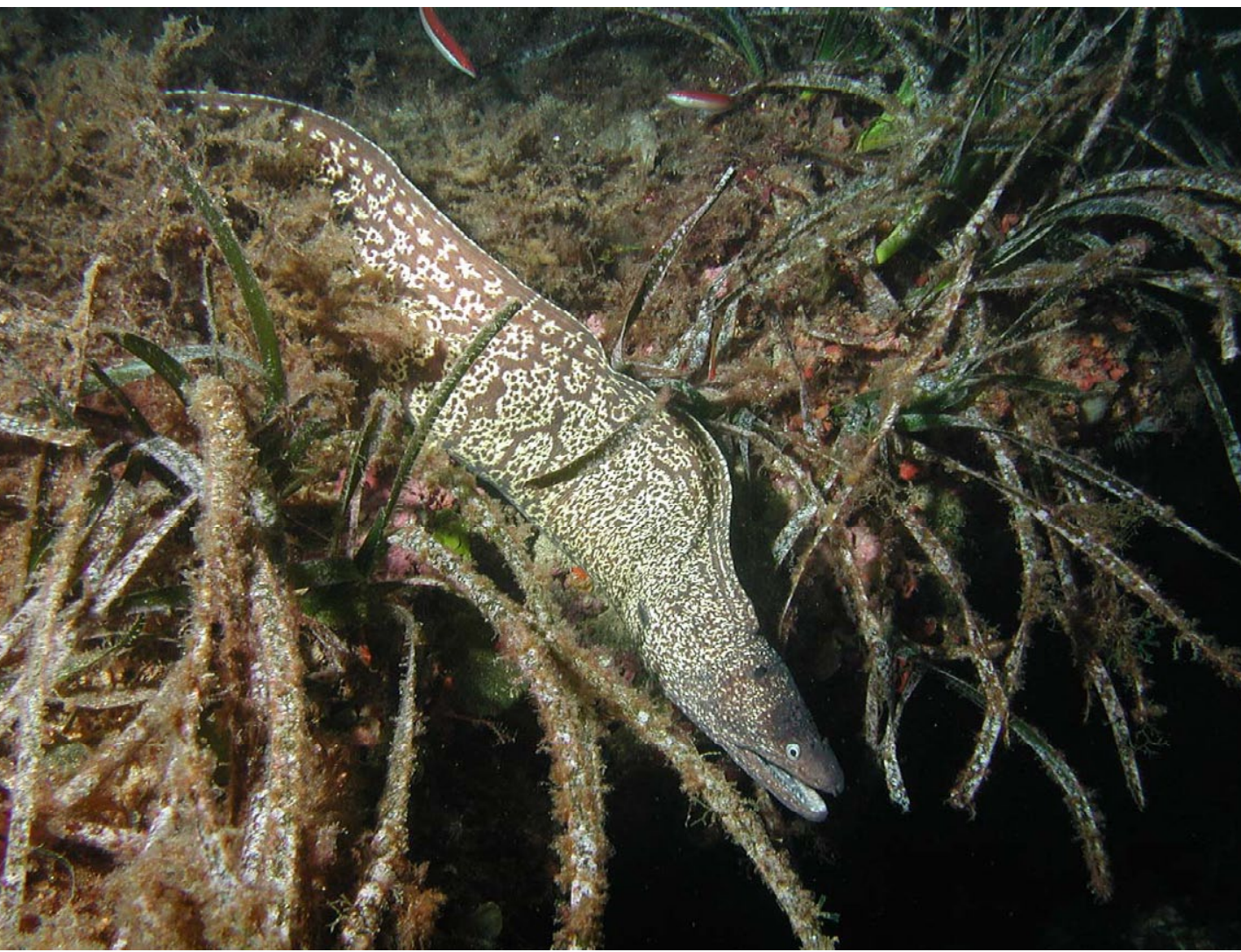

MEDITERRANEA. SERIE DE ESTUDIOS BIOLÓGICOS. 2011 ÉPOCA II. NÚMERO ESPECIAL

COMITÉ EDITORIAL:

G.U. Caravello

S.G. Conard

A. Farina

L. Taïqui

J.L. Sánchez

P. Sánchez

J. Bayle

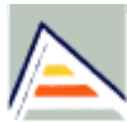

Universitat d'Alacant

Universidad de Alicante
Con la colaboración de:

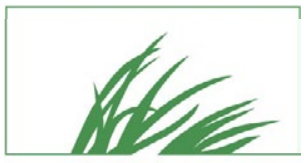

Fundación Biodiversidad 
COMITÉ CIENTÍFICO:

S. G. CONARD. USDA Forest Service. Riverside. U.S.A.

A. FARINA. Lab. Ecologia del Paisaje. Museo Historia Natural. Aulla. Italia.

A. FERCHICHI. I.R.A. Medenine. Túnez.

G.U.CARAVELLO. Istituto di Igiene. Università di Padova. Italia.

L. TAÏQUI. Université Abdelmalek Essaâdi. Tetuán. Marruecos.

COMITÉ EDITORIAL:

V. Peiró, J. Martín, A.Pastor-López, E. Seva.

DIRECCIÓN:

Eduardo Seva. Dep. Ecología. Fac. de Ciencias. Universidad de Alicante.

SECRETARÍA:

Victoriano Peiró (V.peiro@ua.es). Dep. Ecología. Universidad de Alicante.

EDITA:

Servicio de Publicaciones. Universidad de Alicante.

http://publicaciones.ua.es

CORRESPONDENCIA:

Departamento de Ecología. Fac. de Ciencias. Universidad de Alicante.

Ap. 99 - 03080 Alicante. España.

Teléfono de Secretaría: +34965903400, ext 2255

Fax: Rev. Mediterránea. Dep. Ecología. 96/5903464

I.S.S.N.: 0210-5004

Depósito Legal: A-1059-1984

Edición electrónica:

E Espagrafic 


\section{Notas para los autores}

Los trabajos versarán sobre aspectos de ecología, recursos naturales, paisaje, gestión ambiental, en los ecosistemas de bioma mediterráneo.

Los manuscritos mecanografiados a doble espacio y por una sola cara se enviarán a la dirección del Departamento de Ecología de la Universidad de Alicante, Ap. 99 (03080 Alicante, España) —Revista Mediterranea-. Los autores deberán enviar original y dos copias, así como en disquette compatible en programas de tratamiento de texto WORD.

LENGUA: Redactados en español, inglés, francés o italiano.

NOMBRE DE AUTORES: Apellidos y nombres sin abreviaciones.

DIRECCIÓN: Dirección profesional (Organización, Centro de Investigación, Universidad,...) teléfono, telefax, dirección electrónica.

TÍTULO: conciso y completo, sin abreviaciones (max. 60 espacios).

RESÚMEN: Después del título, un resumen en inglés y otro en francés, de 1500 espacios como máximo, independientemente de la lengua utilizada en el texto del trabajo

PARÁGRAFOS: El manuscrito debe respetar el siguiente orden: (contenido) introducción sin título, parágrafos con títulos cortos (max. 50 espacios), conclusiones, agradecimientos (si procede), referencias bibliográficas.

REFERENCIAS BIBLIOGRÁFICAS: Obligatorias para las publicaciones citadas en el texto, que irán en mayúscula. Las referencias de información no publicada (informes, comunicación personal...) se incluyen en el texto entre paréntesis. La bibliografía se presentará según los modelos siguientes:

GOSZ, J.R. and SHARPE, J.H. 1989. Broad-scale concepts for interactions of climate, topography, and biota and biome transitions. Landscape Ecology 3:229-243. 
PIANKA, E. 1986. Ecology and natural history of desert lizards. Princeton University Press. Princeton, New Jersey.

GOLDSMITH, V. 1979. Coastal dunes. In: R.A. Davis (ed.), Coastal sedimentary environments. New York:Springer-Verlag.

CORRECCIÓN DE PRUEBAS: Será realizada por la redacción de la revista, aunque los autores deben enviar un texto muy claro y definitivo. Si se hallan deficiencias notorias en el texto, el trabajo será remitido a los autores de inmediato.

TABLAS: Cada tabla en página por separado, numeradas siguiendo el orden de aparición en el texto y llevarán leyenda. El método de escritura admitido puede ser WORD o EXCEL.

GRÁFICAS y DIBUJOS: Presentados en papel blanco no reciclado, exclusivamente en blanco y negro. Las láminas en color deberán ser costeadas por los autores. Gráficas y dibujos deben ser presentados de forma que, modificando su dimensión, no se vea modificada su comprensión. Deberán acompañar las leyendas al gráfico, suficientemente grandes e incluidas en la caja del mismo. Es obligatorio acompañar archivo en disco compatible y formato TIF o JPGE.

ILUSTRACIONES: Las fotografías, separadas del texto, con leyenda y número de orden, posición en el texto, etc.

NOTAS: Excepcionalmente se incluirán notas a pie, pero éstas deben ir en hojas separadas y debidamente numeradas.

EXTENSIÓN: El texto comprenderá una extensión de 5 (min.) a 25 (max.) páginas mecanografiadas. El numero de gráficos, dibujos y fotografías debe ser proporcional al tamaño del texto.

La dirección de la revista se reserva el derecho de revisar los trabajos presentados con el fin de adaptarlos a la publicación.

http://publicaciones.ua.es 


\section{Notes for the authors}

\section{SUBJECTS}

\section{Ecology}

Natural Resources

\section{Landscape}

\section{Environmental Management}

Manuscripts typed on duplicate on one side of the sheet only, should be sent to the magazine direction: Mediterranea. S.E.B.Dep. Ecologia. Universidad de Alicante. Ap. 99 (03080 Alicante) Spain. All authors are kindly requested to send their papers in writing, but namely on MS DOS/ IBM compatible disks, using WORD program. Every paper should conform to the following rules:

LANGUAGE: Spanish, English, French or Italian.

NAME OF THE AUTHORS: Preceded by the full first name without abbreviations.

ADDRESS: Institutional address of author(s) (Institutions, Research Centre, University), telephone, fax, electronic adress..

TITLE: Concise but detailed enough, without abbreviations (max. 60 strokes).

ABSTRACTS: In English and French, whatever it might be the language of the paper. The lenght should not exceed 1500 strokes.

PARAGRAPHS: Should be arranged as follows: (contents) introduction without title, paragraphs with short titles (max. 50 strokes), conclusions, acknowledgments (if required), references.

REFERENCES: Should include only publications mentioned in the text. References to unpublished informations (reports, personal communications, etc.) should be included between parentheses in the text. The bibliography should be presented in conformity with the following patterns: GOSZ, J.R. and SHARPE, J.H. 1989. Broad-scale concepts for interac- 
tions of climate, topography, and biota and biome transitions. Landscape Ecology 3:229-243.

PIANKA, E. 1986. Ecology and natural history of desert lizards. Princeton University Press. Princeton, New Jersey.

GOLDSMITH, V. 1979. Coastal dunes. In: R.A. Davis (ed.), Coastal sedimentary environments. New York:Springer-Verlag.

CORRECTIONS TO THE PROOF: Will be done by the editorial staff. Authors are kindly requested to submit a clear and final paper.

TABLES: Each table should be on a separate sheet, numbered consecutively, with a legend. The writing method admitted is WORD, EXCEL..

GRAPHICS AND DRAWINGS: Separated from the text, should be lettered on white or glossy paper, in black and white in compatible disks TIF or JPGE format. They should be clearly "constructed", with sufficiently big letters within the block of the graph.

ILLUSTRATIONS: Photographs should be numbered and lettered.

NOTES: They should be numbered and referred to in the text. They should be compiled on separate sheets.

LENGHT: Preferably between 5 (min.) and 25 (max.) typed pages. The number of illustrations, tables and graphs should be proportional to the lenght of the text.

The articles are reviewed by the editorial staff to be conformed for their publication.

http://publicaciones.ua.es 
A. Jurado-Ruzafa, M.N. Carrasco Henarejos, V. Duque Nogal, A. Sancho Rafel, E. HeRnández RodRÍGUEZ, P.J. PASCUAL Alayón Y M.T. GaRcía SANTAMARÍA

Preliminary data on horse mackerel (Trachurus spp) landings from Mauritanian waters 
Índice

\section{Portada}

\section{Créditos}

Abstract

Résumé

Introduction.

Material and methods.

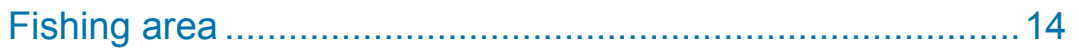

Control of landings and collection of samples ...................... 14

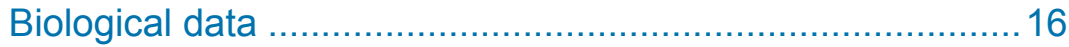

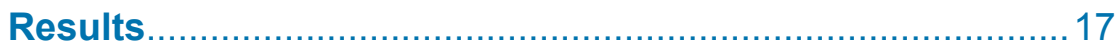

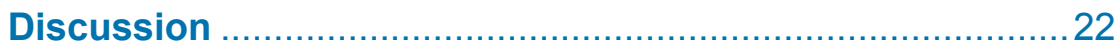

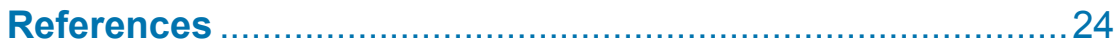

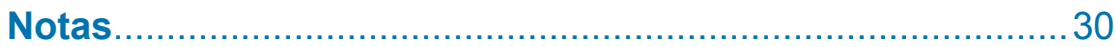




\title{
Preliminary data on horse mackerel (Trachurus spp) landings from Mauritanian waters
}

\author{
A. Jurado-Ruzafa (1), M.N. Carrasco Henarejos (1), \\ V. Duque Nogal (1), A. SAncho Rafel (1), E. HeRnándeZ \\ Rodríguez (1), P.J. PAscual Alayón (1) y M.T. García \\ SANTAMARÍA (1)
}

\section{Abstract}

European fishery off Mauritania (one of the most productive and most intensively exploited regions in the world) targeted to small pelagic fish accounts for $30 \%$ of the total catches in the area. The Instituto Español de Oceanografía (IEO), through its Centro Oceanográfico de Canarias, follows up the activity of these vessels that land at Spanish port (Las Palmas de Gran Canaria, Spain), under the European Project Data Collection (Regulation (EC) 1543/2000). One of the target groups in this fishery is Trachurus spp, commercially named "JAX". 
A. Jurado-Ruzafa, M.N. Carrasco Henarejos, V. Duque Nogal, A. Sancho Rafel, E. Hernández Rodríguez, P.J. Pascual Alayón y M.T. García Santamaría

During 2008 and 2009, several samples of this group from these landings were analysed, and Caranx rhonchus was the second species of importance. The mixture of these species in the landings of this UE fleet should be determined to improve the data provided to the international Working Groups responsible for assessment of those resources.

Key words: Trachurus spp, Caranx rhonchus, small pelagic fishes, Mauritania, mixed fisheries.

\section{Résumé}

La pêcherie européenne au long de côte de la Mauritanie (l'une des régions les plus productives et les plus intensément exploitées du monde) dirigée aux petits poissons pélagiques forme le $30 \%$ des captures totales dans la région. L'Institut Espagnol d'Océanographie (IEO), par son Centro Oceanográfico de Canarias, suit l'activité de ces navires qui déchargent dans port espagnol (Las Palmas de Gran Canaria, Espagne), sous le projet européen de collecte de données (règlement (EC) 1543 / 2000).

L'un des groupes objectif de cette pêcherie est Trachurus spp, commercialement appelé «JAX». En 2008 et 2009, on a analysé plusieurs échantillons de ce groupe à partir de ces débarquements, et Caranx rhonchus était la deuxième espèce 
Preliminary data on horse mackerel (Trachurus spp) landings from Mauritanian waters

en importance. Le mélange de cette espèce dans les débarquements de cette flotte de l'UE devrait être déterminée, pour améliorer les données offertes aux groupes de travail internationaux, responsables de l'évaluation de ces ressources.

Mots-clés: Trachurus spp, Caranx rhonchus, petits poissons pélagiques, Mauritanie, pêcheries mixtes.

\section{Introduction}

he Northwest African shelf is considered as one of the most productive and most intensively fished areas in the world (Zeeberg et al., 2006; Fréon et al., 2008; Arkhipov, 2009; Fischer et al., 2009; Lidvanov et al., 2010; Meiners et al., 2010). The special environment conditions support important fish resources (among which the small pelagic are the most abundant), and the fishery sector plays an important role in the economies of the different countries of the region.

Small pelagic resources are exploited not only by artisanal fishing (canoes, open boats powered by outboard engines with less than $100 \mathrm{hp}$ or sailing boats (Campredon and Cuq, 2001)), but also by great pelagic trawlers (almost exclusively foreign) (FAO, 2008). Despite their relatively low commercial value, the small pelagic fish are dominating the catches 
A. Jurado-Ruzafa, M.N. Carrasco Henarejos, V. Duque Nogal, A. Sancho Rafel, E. Hernández Rodríguez, P.J. Pascual Alayón y M.T. García Santamaría

and are important to both the industrial and artisanal sectors (Samb, 2002).

European fisheries off Mauritania are possible through international access agreements and private arrangements, which enable foreign trawlers to exploit the potential of this highly productive upwelling system (ter Hofstede and Dickey-Collas, 2006). Dutch and Irish boats are amongst the largest fishing vessels in the world; in the Mauritanian Exclusive Economic Zone, they operate within miles of each other and are often accompanied by dozens of Russian, Lithuanian, and Icelandic trawlers (Zeeberg et al., 2006).

Although the Spanish fleet does not operate this fishery, it is considered to be of great interest in the UE for monitoring and sampling because it is a European Community fleet with a high catch volume (30\% of the total in the area). Since 2003, the Instituto Español de Oceanografía (IEO), through its Centro Oceanográfico de Canarias (COC, in Tenerife, Canary Islands), follows up the activity of the vessels that land at Spanish port (Las Palmas de Gran Canaria, Spain), under the European Project Data Collection (Regulation (EC) 1543/2000).

The European pelagic fleet fishing in Mauritania targets mainly five species: sardine (Sardina pilchardus (Walbaum, 1792)), 
Preliminary data on horse mackerel (Trachurus spp) landings from Mauritanian waters

round sardinella (Sardinella aurita Valenciennes, 1847), flat sardinella (Sardinella maderensis (Lowe, 1838)), mackerel (Scomber colias Gmelin, 1789) and horse mackerels (Trachurus spp). Some of these vessels land the most catches in the Puerto de la Luz (Las Palmas de Gran Canaria, Spain). These pelagic freezer-trawlers consisted of 5 vessels in 2008 and 7 in 2009, from The Netherlands, France, England and Ireland, having engine powers ranging from 3,000 and 8,000 $\mathrm{hp}$ and equipped to sort and process fish into deep-frozen packages (García Santamaría et al., 2010). In addition to the biological information obtained from other target species, in 2008 the COC began the study of horse mackerel (Trachurus spp) under the commercial codification "JAX".

In the last decade, the Food and Agriculture Organization of the United Nations (FAO) has hosted the annual International Working Group Resources Assessment of Small Pelagic distributed in Northwest Africa, whose final aim is to determine the operational status of such management and make assessment proposals to ensure the conservation and sustainability of the fisheries involved.

These Working Groups have considered, in the monitoring of horse mackerel fisheries, that "Exploitation is geared towards three species: the Atlantic horse mackerel (Trachurus trachu- 
A. Jurado-Ruzafa, M.N. Carrasco Henarejos, V. Duque Nogal, A. Sancho Rafel, E. Hernández Rodríguez, P.J. Pascual Alayón y M.T. García Santamaría

rus (Linnaeus, 1758)), the Cunene horse mackerel (Trachurus trecae Cadenat, 1950) and the false scad (Caranx rhonchus Geoffroy Saint-Hilaire, 1817). The two main species in terms of the assessment are Trachurus trachurus and Trachurus trecae, while the third species is caught as bycatch. Therefore, for this species (Caranx rhonchus), only data on catch and abundance indices obtained during acoustic surveys will be given" (FAO, 2008).

The present study aims to highlight the noticeable presence of one species of another genus (Caranx) in the reported information of Trachurus spp landed by this UE fleet, in order to ameliorate the quality of data used in the assessments and in the establishment of their levels of exploitation.

\section{Material and methods}

\section{Fishing area}

This study considers catches and UE fleet monitored from Mauritanian waters, covering the FAO subdivisions 34.1.32 and 34.3.11 (Fig. 1).

\section{Control of landings and collection of samples}

Since January 2008 to December 2009, catch declarations at the port of Las Palmas de Gran Canaria by species and com- 


\section{Preliminary data on horse mackerel (Trachurus spp) landings}

from Mauritanian waters

mercial category, and fishing effort data were provided by the fishing inspection office (belonging to the Spanish Ministry of Agriculture, Fisheries and Food).

Samples were selected and provided frozen in boxes that are identified by an alphanumerical code: letters identify the spe-

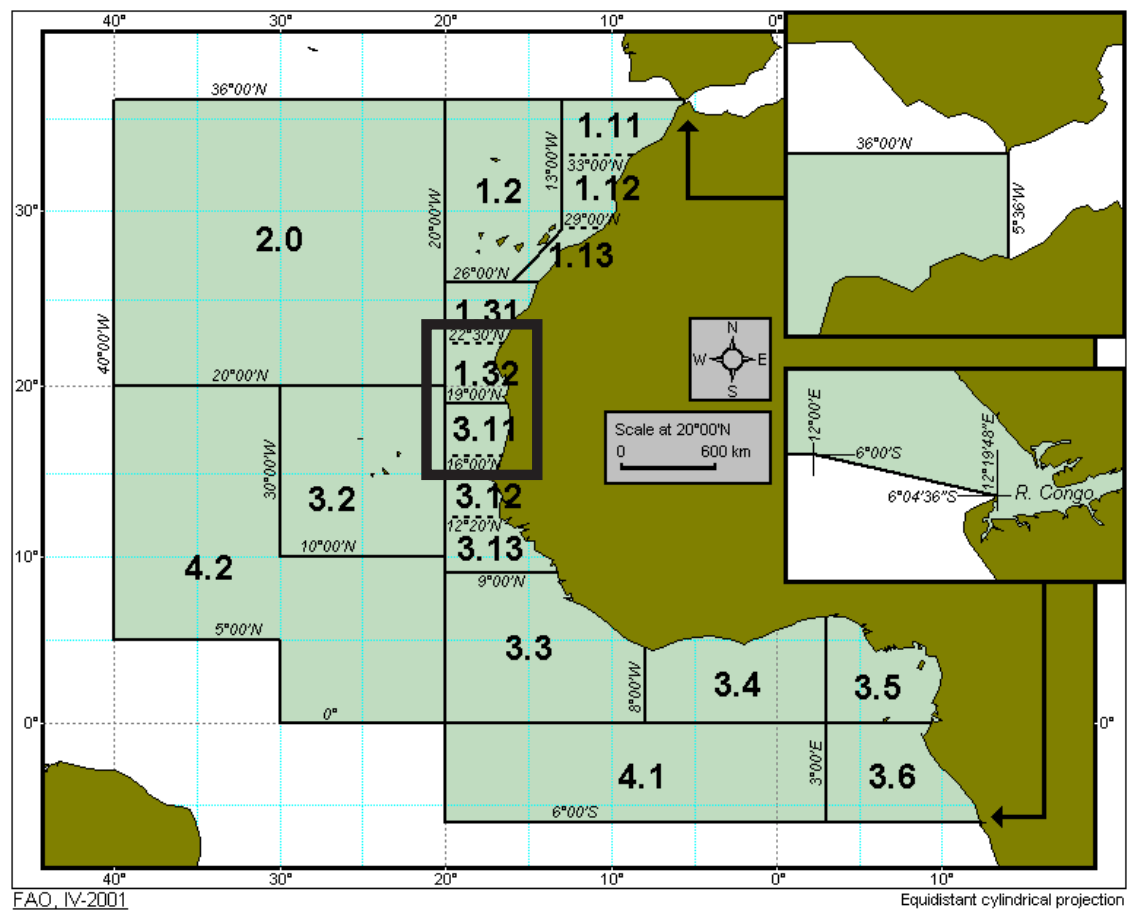

Figure 1. Major Fishing Area 34 (FAO, 1990-2011). The studied area (rectangle) covers the Mauritanian waters. 
A. Jurado-Ruzafa, M.N. Carrasco Henarejos, V. Duque Nogal, A. Sancho Rafel, E. Hernández Rodríguez, P.J. Pascual Alayón y M.T. García Santamaría

cies contained (SAA is $S$. aurita; SAE is $S$. maderensis; PIL is S. pilchardus; MAS is S. japonicus; JAX is Trachurus spp), and the number corresponds to the commercial categories, number of fishing trips and the code of the vessel.

\section{Biological data}

During the studied period, 5,105 specimens of "JAX" from commercial catches were analysed.

Firstly, all the fishes were sorted by species. Then, they were measured using an ichthyometer for total length ( $T L$, precision $0.1 \mathrm{~cm}$ ), and weighed using a precision balance for total weight (TW, precision $0.1 \mathrm{~g}$ ). Length frequency distributions by species were analysed.

Length-Weight relationships were obtained for each species by the adjustment of an exponential curve to the data $\mathrm{W}=$ $a \cdot L^{b}$ ( $a$ and $b$ were estimated by linear regression of logarithmically transformed length-weight data) (Ricker, 1973). To establish the nature of the allometric length-weight relationships, modified t-Student tests were calculated from the $b$ estimates (Pauly, 1984). In addition, an analysis of covariance (ANCOVA) was applied for analysis of statistical differences between the length-weight relationships, using the software GraphPad Prism ${ }^{\circledR} 4$. 
Preliminary data on horse mackerel (Trachurus spp) landings from Mauritanian waters

\section{Results}

Discharges of "JAX" were about 1,500 tons in 2008 (22 fishing trips) and 2,000 tons in 2009 (29 fishing trips) (Fig. 2).

Fishing effort was higher during spring and summer in both years, with a drop in April to June. A total stop occurred in September 2008 and February 2009. The highest catches were obtained in May and in the last months of monitored years, being less important in the second period.

Proportions of identified species in analysed "JAX" samples (in order of importance: Trachurus trecae, Caranx rhonchus,

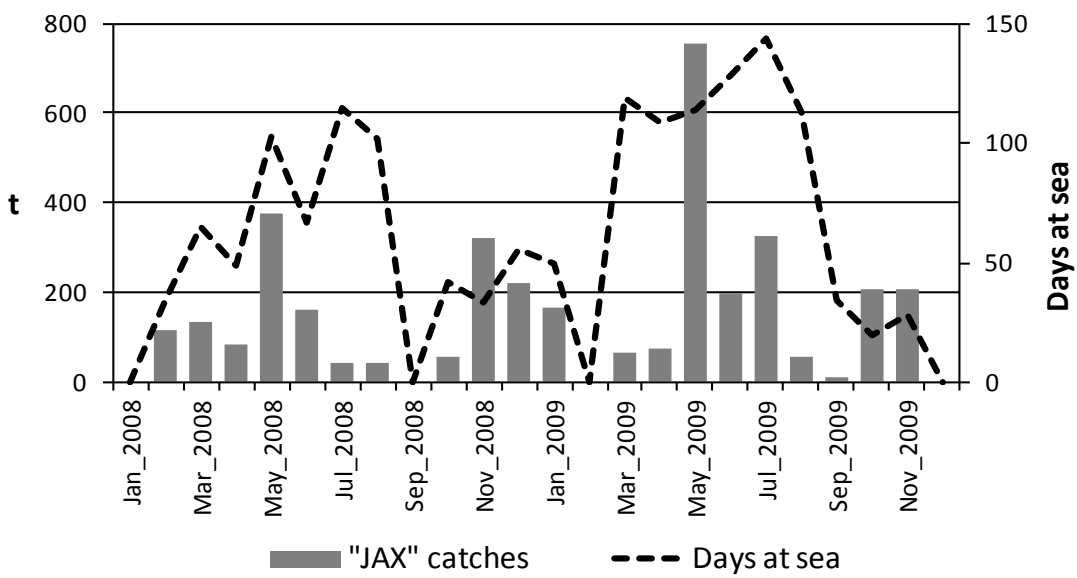

Figure 2. Monthly "JAX" landings (t) and fishing effort (days at sea) of the UE fleet monitored fishing off Mauritania, during 2008 and 2009. 
A. Jurado-Ruzafa, M.N. Carrasco Henarejos, V. Duque Nogal, A. Sancho Rafel, E. Hernández Rodríguez, P.J. Pascual Alayón y M.T. García Santamaría
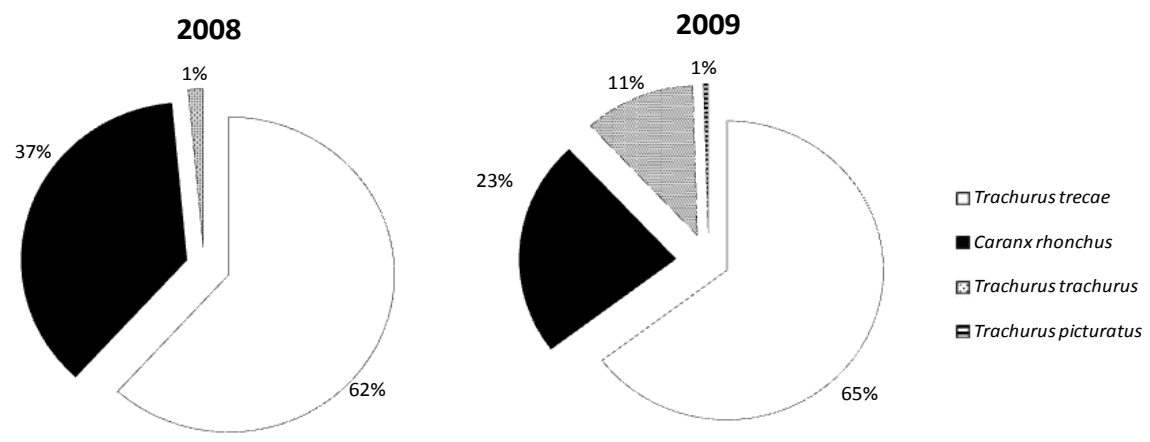

Figure 3. Percentages for species found in samples commercialised as Trachurus spp (or "JAX") analysed between 2008 and 2009, from EU Fleet landings fished off Mauritania.

Trachurus trachurus and Trachurus picturatus (Bowdich, 1825)), are shown on Figure 3:

The most abundant species was Trachurus trecae, with a similar percentage in both years $(>60 \%)$ and $C$. rhonchus was the second one in commercial landings analysed under "JAX" codification (37\% in 2008 and $23 \%$ in 2009). Trachurus trachurus augmented from $1 \%$ in 2008 to $11 \%$ in 2009 . Finally, some specimens of Trachurus picturatus were found in the analysed samples corresponding to 2009 .

The length range analysed, length means and dominant length classes were very different for each species (Table I). 
Preliminary data on horse mackerel (Trachurus spp) landings from Mauritanian waters

\begin{tabular}{|l|c|c|c|c|}
\hline & $\mathbf{N}$ & $\begin{array}{c}\text { Length range } \\
\mathbf{( c m )}\end{array}$ & $\begin{array}{c}\text { Length } \\
\text { mean }(\mathbf{c m})\end{array}$ & $\begin{array}{c}\text { Dominant length } \\
\text { class } \mathbf{( c m})\end{array}$ \\
\hline T. trecae & 3,336 & $17.6-49.5$ & 27.1 & 22 and 27 \\
\hline C. rhonchus & 1,242 & $21.0-45.4$ & 29.4 & 28 \\
\hline T. trachurus & 509 & $19.7-30.6$ & 23.2 & 22 \\
\hline T. picturatus & 18 & $20.2-28.7$ & 23.5 & 23 \\
\hline
\end{tabular}

Table I. Summary of length sampling data obtained during 2008 and 2009 for "JAX" samples.

Except for $T$. picturatus (owing to the few specimens found in landings), length frequency distributions are presented in Fig. 4. The most remarkable is that $T$. trecae showed a bimodal distribution.

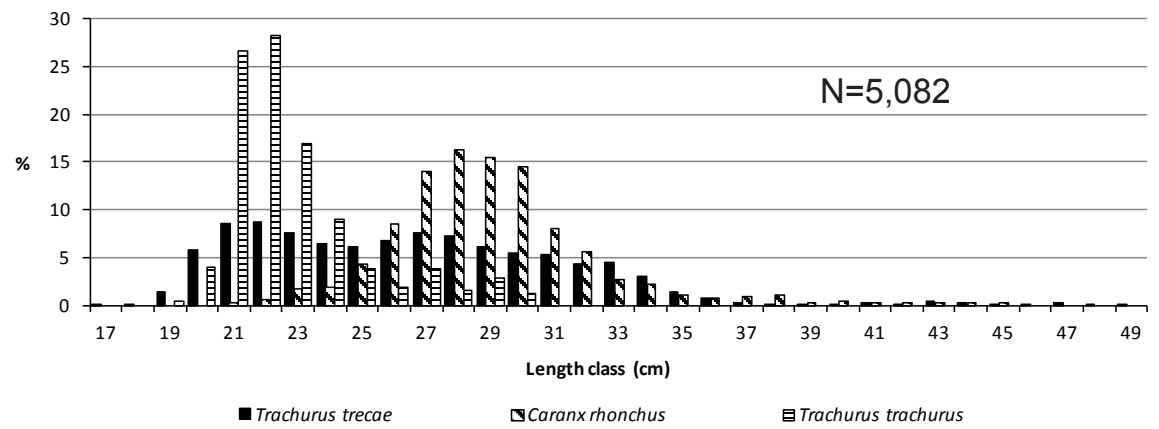

Figure 4. Length frequency distributions for the four species, from length sampling data of "JAX" samples analysed between 2008 and 2009. 
A. Jurado-Ruzafa, M.N. Carrasco Henarejos, V. Duque Nogal, A. Sancho Rafel, E. Hernández Rodríguez, P.J. Pascual Alayón y M.T. García Santamaría
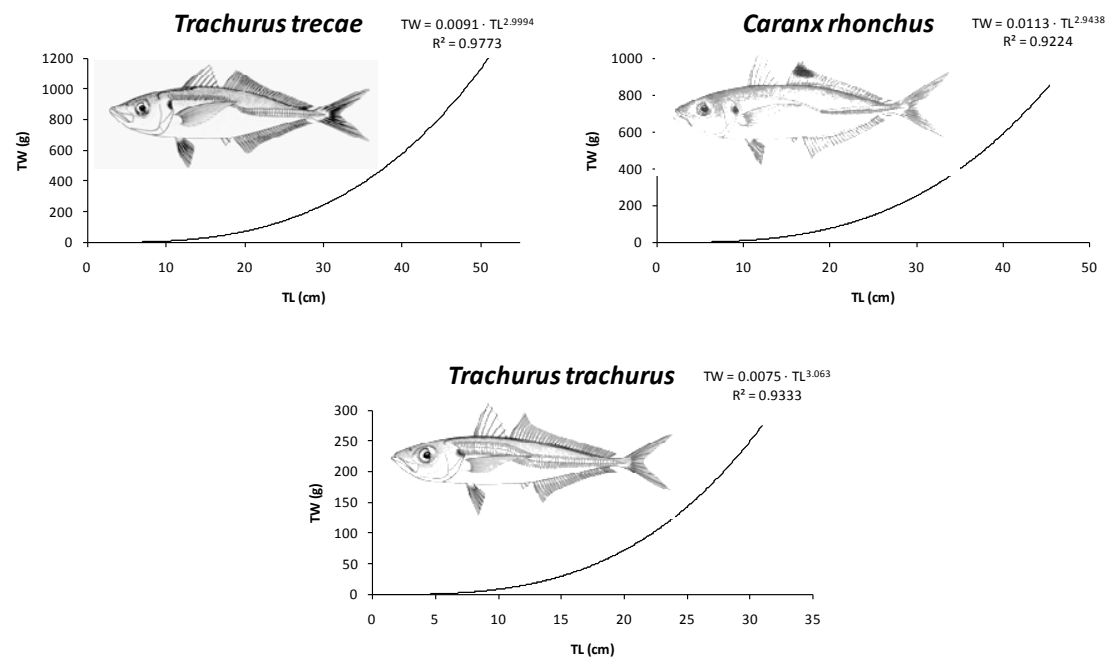

Figure 5. Length-Weight relationships estimated for Trachurus trecae, Caranx rhonchus and Trachurus trachurus. TW = Total Weight; $\mathrm{TL}=$ Total Length. (Illustrations from Fischer et al., 1981).

Length-Weight relationships are shown in Figure 5. Because the number of samples of $T$. picturatus is insufficient $(n=18)$, its parameters were not estimated.

Summary of results obtained from the t-Student tests are shown on Table II. Each species showed different kinds of allometric Length-Weight relationships.

All cross ANCOVA analyses conclude that the differences between the slopes are significant $(p<0.01)$. 
Preliminary data on horse mackerel (Trachurus spp) landings from Mauritanian waters

\begin{tabular}{|l|c|l|}
\hline & \multicolumn{1}{|c|}{$\mathbf{t}$} & \multicolumn{1}{c|}{ Conclusion } \\
\hline T. trecae & 0.0758 & $=3$ : isometric growth* \\
\hline T. trachurus & 17.324 & $>3:$ positive allometry** \\
\hline C. rhonchus & 23.177 & $<3:$ negative allometry ${ }^{* * *}$ \\
\hline
\end{tabular}

*not significantly different from $3(p<0.4)$

**significantly different from $3(p<0.05)$

${ }^{* * *}$ significantly different from $3(p<0.025)$

Table II. Results of the t-Student test (modified by Pauly, 1984).

Graphical results of applying the percentages of each species to total catches (Fig. 2) are represented on Figure 6.

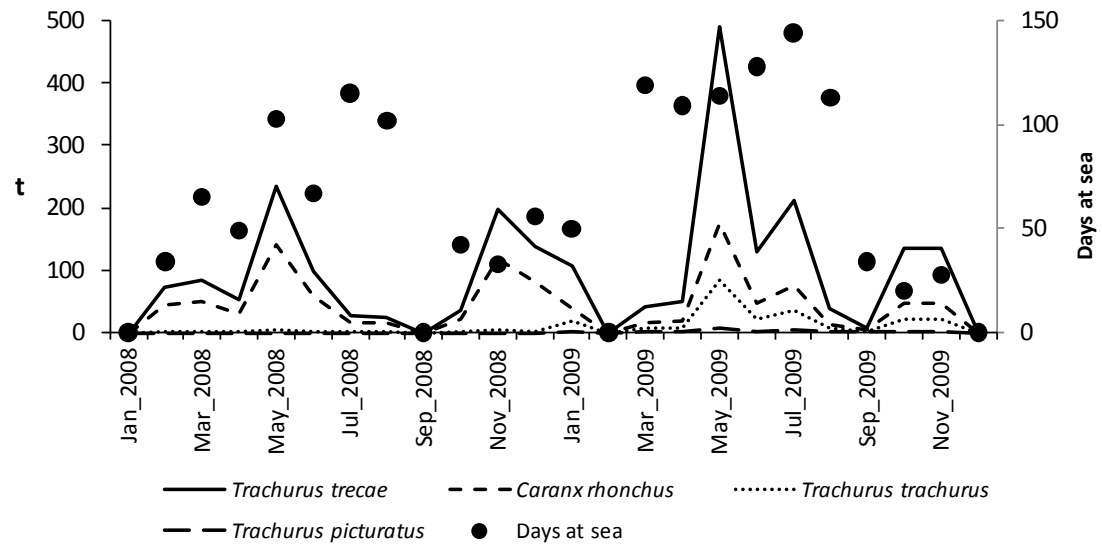

Figure 6. Total "JAX" catches by species, based on percentages estimated from length-weight samplings. 
A. Jurado-Ruzafa, M.N. Carrasco Henarejos, V. Duque Nogal, A. Sancho Rafel, E. Hernández Rodríguez, P.J. Pascual Alayón y M.T. García Santamaría

\section{Discussion}

The population parameters Length-Weight relationships showed important differences between the analysed species. Also, literature provides radical differences between their reproduction and spawning areas and seasons (Garcia, 1982; Abaunza et al., 2008; Froese and Pauly, 2011), and about other ecological aspects on the biology of these species (Blackburn and Nellen, 1976; Kompowski, 1976; Lloris and Moreno, 1995). The scarce number of specimens of T. picturatus found in samples could be due to the low presence of this species in the studied area.

No correlation between fishing effort and "JAX" catches would be explained by the characteristics of this fleet. On one hand, these vessels target a considerable number of species, where Trachurus spp, although its commercial value is higher than for the other species, is the less abundant in landings (Ould et al., 1999; ter Hofstede and Dickey-Collas, 2006). On the other hand, this fleet is able to quickly move their effort to a more abundant species (Maxim, 1995). Therefore, total catches (including all the species) could be increased when fishing effort rose.

The assessments of the status of these resources from Northwest African waters are focused on T. trecae and T. trachurus, 
Preliminary data on horse mackerel (Trachurus spp) landings from Mauritanian waters

the most common species in the area (Blackburn and Nellen, 1976). Previous studies of the area had not considered this mixture and deal with Trachurus spp (Ould et al., 1999; ter Hofstede and Dickey-Collas, 2006). Data from vessels (e.g. landing reports) are a very important source of information for evaluations and the fisheries management whom consider Trachurus spp as a mixture of species of the genus. Trachurus trecae is the most important species among the Trachurus spp catches, being T. trachurus the second one (FAO, 2008). However, during this work, an extreme presence of Caranx rhonchus was found in samples from these catches.

Theoretically, the three species are independently assessed (FAO, 2008) but, in fact, at least this fleet declares the three species as Trachurus spp catches. This is a new challenge in assessing the stocks of those fishes where many difficulties have been described by other authors (Maxim, 1995; Ould et al., 1999; Samb, 2002; ter Hofstede and Dickey-Collas, 2006). Although data provided by Spanish researchers to FAO Working Groups are sorted by species, data supplied by ship owners about catches and effort are confused and insufficient.

Other fishing methods (i.e. fisheries that use Fish Aggregating Devices) have similar problems to produce independent spe- 
A. Jurado-Ruzafa, M.N. Carrasco Henarejos, V. Duque Nogal, A. Sancho Rafel, E. Hernández Rodríguez, P.J. Pascual Alayón y M.T. García Santamaría

cies assessment. But a lot of studies have used techniques to get better knowledge about mixed resources, mainly through acoustic technologies (Massé et al., 1996; Scalabrin et al., 1996; Lawson et al., 2001; Mackinson et al., 2004; Doray et al., 2007; Llambrich and Alvarez, 2009). In other cases, important commercial fisheries occur in mixed shoals, and they are managed together (De Oliveira and Butterworth, 2004).

In the present case, where fisheries with multispecific landings reported by groups of species Trachurus spp are being considered, it is necessary to maintain a sampling program in the landings and follow up interannual fluctuations in the proportion of each species, because each one fluctuates independently. Therefore, to achieve a better assessment and management of fisheries, it would be necessary disaggregate data on landings by species.

\section{References}

ABAUNZA, P., GORDO, L.S., SANTAMARÍA, M.T.G., IVERSEN, S.A., MURTA, A.G. and GALLO, E. 2008. Life history parameters as basis for the initial recognition of stock management units in horse mackerel (Trachurus trachurus). Fisheries Research. 89 (2): 167180.

ARKHIPOV, A. 2009. Seasonal and interannual variation of ichthyoplankton off Mauritania. Journal of Ichthyology. 49 (6): 460-468. 


\section{Preliminary data on horse mackerel (Trachurus spp) landings from Mauritanian waters}

BLACKBURN, M. and NELLEN, W. 1976. Distribution and ecology of pelagic fishes studied from eggs and larvae in an upwelling area off Spanish Sahara. Fishery Bulletin. 74 (4): 885-896.

CAMPREDON, P. and CUQ, F. 2001. Artisanal Fishing and Coastal Conservation in West Africa. Journal of Coastal Conservation. 7 (1): 91-100.

DE OLIVEIRA, J.A.A. and BUTTERWORTH, D.S. 2004. Developing and refining a joint management procedure for the multispecies South African pelagic fishery. ICES Journal of Marine Science. 61 (8): 1432-1442.

DORAY, M., JOSSE, E., GERVAIN, P., REYNAL, L. and CHANTREL, J. 2007. Joint use of echosounding, fishing and video techniques to assess the structure of fish aggregations around moored Fish Aggregating Devices in Martinique (Lesser Antilles). Aquatic Living Resources. 20 (4): 357-366.

FAO. 1990-2011. FAO Major Fishing Areas fact sheets. Atlantic, Eastern Central (Major Fishing Area 34). CWP Data Collection [Online]. Rome. Available: http://www.fao.org/fishery/area/search/en [Accessed 2011].

FAO. 2008. Report of the FAO Working Group on the Assessment of Small Pelagic Fish off Northwest Africa. Saly, Senegal, 6-15 May 2008. FAO Fisheries and Aquaculture Report. Rome.

FISCHER, G., REUTER, C., KARAKAS, G., NOWALD, N. and WEFER, G. 2009. Offshore advection of particles within the Cape 
A. Jurado-Ruzafa, M.N. Carrasco Henarejos, V. Duque Nogal, A. Sancho Rafel, E. Hernández Rodríguez, P.J. Pascual Alayón y M.T. García Santamaría

Blanc filament, Mauritania: Results from observational and modelling studies. Progress In Oceanography. 83 (1-4): 322-330.

FISCHER, W., BIANCHI, G. and SCOTT, W.B. (eds.). 1981. FAO species identification sheets for fishery purposes Eastern Central Atlantic; Fishery Areas 34, 47 (in part). Dep. of Fisheries and Oceans, Canada, by arrangement with the Food and Agriculture Organization of the United Nations. Ottawa, Canada.

FRÉON, P., BARANGE, M. and ARÍSTEGUI, J. 2008. Eastern boundary upwelling ecosystems: integrative and comparative approaches. Abstracts Book. Las Palmas de Gran Canaria.

FROESE, R. and PAULY, D. 2011. FishBase. World Wide Web electronic publication [Online]. Available: www.fishbase.org, version 01/2010 [Accessed 2011].

GARCIA, S. (ed.) 1982. Distribution, migration and spawning of the main fish resources in the Northern CECAF Area. FAO. CECAF/ ECAF Series. Rome.

GARCÍA SANTAMARÍA, M.T., SANCHO RAFEL, A., JURADO-RUZAFA, A., DUQUE NOGAL, V., CARRASCO HENAREJOS, M.N., ROMERO ROMERO, Z., FERNÁNDEZ PERALTA, L., GARCÍA ISARCH, E., PASCUAL ALAYÓN, P.J., PUERTO GONZÁLEZ, M.A., HERNÁNDEZ RODRÍGUEZ, E., REY SANZ, J. and SALMERÓN JIMÉNEZ, F. 2010. Scientific-Technical Report National Basic Data Collection Programme. Committee for Eastern Central Atlantic Fisheries. Centro Oceanográfico de Canarias-IEO. Madrid: $64 \mathrm{pp}$. 


\section{Preliminary data on horse mackerel (Trachurus spp) landings from Mauritanian waters}

KOMPOWSKI, A. 1976. A study on the food and feeding habits of Trachurus trachurus, Trachurus trecae, Trachurus picturatus and Caranx rhonchus in the region of Cape Blanc. Acta Ichthyologica et Piscatoria. 6 (1): 35-57.

LAWSON, G.L., BARANGE, M. and FRÉON, P. 2001. Species identification of pelagic fish schools on the South African continental shelf using acoustic descriptors and ancillary information. ICES Journal of Marine Science: Journal du Conseil. 58 (1): 275-287.

LIDVANOV, V.V., ZHIGALOVA, N.N. and KUDERSKIY, S.K. 2010. Vertical distribution of mesozooplankton in the interaction zone of the Canary and the Northern Branch of the Intertrades currents. Oceanology. 50 (3): 356-364.

LLAMBRICH, E. and ALVAREZ, L. 2009. Discriminación de especies mediante ecosonda científica EK60. A Fondo: Todo sobre la tecnología aplicada al sector naval. SIMRAD.

LLORIS, D. and MORENO, T. 1995. Distribution model and association in three pelagic congeneric species (Trachurus spp.) present in the Iberic Mediterranean Sea. Scientia Marina. 59 (3-4): 399-403.

MACKINSON, S., FREEMAN, S., FLATT, R. and MEADOWS, B. 2004. Improved acoustic surveys that save time and money: integrating fisheries and ground-discrimination acoustic technologies. Journal of Experimental Marine Biology and Ecology. 305 (2): 129-140.

MASSÉ, J., KOUTSIKOPOULOS, C. and PATTY, W. 1996. The structure and spatial distribution of pelagic fish schools in multispecies 
A. Jurado-Ruzafa, M.N. Carrasco Henarejos, V. Duque Nogal, A. Sancho Rafel, E. Hernández Rodríguez, P.J. Pascual Alayón y M.T. García Santamaría

clusters: An acoustic study. ICES Journal of Marine Science. 53 (2): 155-160.

MAXIM, C. 1995. Horse mackerel and false scad stock assessment and catch projections, CECAF Divisions 34.1.3 and 34.3.1. Scientia Marina. 59 (3-4): 611-627.

MEINERS, C., FERNÁNDEZ, L., SALMERÓN, F. and RAMOS, A. 2010. Climate variability and fisheries of black hakes (Merluccius polli and Merluccius senegalensis) in NW Africa: A first approach. Journal of Marine Systems. 80 (3-4): 243-247.

OULD, S., SHAW, R.F. and GEAGHAN, P.J. 1999. On the dynamics of the Mauritanian small-pelagic fishery, North-West Africa. South African Journal of Marine Sciences. 21: 135-144.

PAULY, D. 1984. Fish Population Dynamics in Tropical Waters: A Manual for Use with Programable Calculators. Manila, Philippines.

RICKER, W.E. 1973. Linear regressions in fishery research. Journal of the Fisheries Research Board of Canada. 30: 409-434.

SAMB, B. 2002. Case Study of Small Pelagic fish resources in Northwest Africa. Norway-FAO Expert Consultation on the Management of Shared Fish Stocks. Bergen, Norway: FAO.

SCALABRIN, C., DINER, N., WEILL, A., HILLION, A. and MOUCHOT, M.-C. 1996. Narrowband acoustic identification of monospecific fish shoals. ICES Journal of Marine Science: Journal du Conseil. 53 (2): 181-188. 
Preliminary data on horse mackerel (Trachurus spp) landings from Mauritanian waters

TER HOFSTEDE, R. and DICKEY-COLLAS, M. 2006. An investigation of seasonal and annual catches and discards of the Dutch pelagic freezer-trawlers in Mauritania, Northwest Africa. Fisheries Research. 77 (2): 184-191.

ZEEBERG, J., CORTEN, A. and DE GRAAF, E. 2006. Bycatch and release of pelagic megafauna in industrial trawler fisheries off Northwest Africa. Fisheries Research. 78 (2-3): 186-195. 
A. Jurado-Ruzafa, M.N. Carrasco Henarejos, V. Duque Nogal, A. Sancho Rafel, E. Hernández Rodríguez, P.J. Pascual Alayón y M.T. García Santamaría

\section{Notas}

1. Centro Oceanográfico de Canarias del Instituto Español de Oceanografía. C/General Gutiérrez, nº4. 38003, Santa Cruz de Tenerife (Spain).

TIf: 922.54 .94 .00

FAX: 922.54.95.54

Correspondingauthor:A.Jurado-Ruzafa.E-mail:alba.jurado@ca.ieo.es 